\title{
Probiotics in animal farming of the Amur region
}

\author{
Natalia Kukharenko ${ }^{1}$ and Anastasia Fedorova ${ }^{1, *}$ \\ ${ }^{1}$ Far Eastern State Agrarian University, 86 Politekhnicheskaya St, Blagoveshchensk, 675005, Russian \\ Federation
}

\begin{abstract}
Normal micro flora in the body is created by probiotics, but in modern environmental conditions and bad economic activity in animal farming this group of microorganisms favorable and very necessary for the body is experiencing a constant and huge pressure, so the quantity and quality of each species of these microorganisms is reduced. The aim of this work is to show the effectiveness of the use of certain probiotics in the animal farming of the Amur region. The research was conducted from 1994 to 2020 in different livestock farms of the Amur region. To assess the condition of animals, there were used generally accepted indicators and the rules of general research. The utmost attention was paid to psychoemotional condition of animals. Body weight indicators were obtained when animals were weighed. As a result, it was found out that the use of probiotics in animal farming of the Amur region showed a positive effect in all cases, but the highest efficiency is provided by "Intestevit "( $94.8 \%$ of the total number of livestock survived). It is manufactured in the laboratory of the Federal State Budgetary Institution "All-Russian State Center for Quality and Standardization of Medicines for Animals and Feed» and it is based on the collection of samples of probiotics from the nomenclature of microflora characteristic of animals from different regions of the Russian Federation. In groups where animals were treated with probiotic "Intestevit", the economic effect was higher by $23.4-25.9 \%$.
\end{abstract}

\section{Introduction}

Physiologically normal and active living of the animal body is provided not only by the work of homeostatic fluids, but also by the normal microflora of organs and tissues. Microbial flora is an association of microorganisms in their interaction with each other and the environment. On various parts of the animal body there are associations of certain microbes that make the so-called normal microflora, which is symbiotic with the macro organism. The microbial flora is always specific to this animal species and has age, regional and seasonal features $[1,2]$.

At present, there are 500 to 800 or more species, subspecies, serotypes and serovars of useful microorganisms whose obligatory cohabitation ensures the full functioning of the whole organism. This microflora plays an important role in digestion, secretory activity of the glandular system, stimulates the immune system, protecting the body from various stresses, unfavorable environmental conditions, preventing and curing a large number of

\footnotetext{
* Corresponding author: anfedka@list.ru
} 
diseases. The normal microbial flora in the body is provided by a probiotic group of microorganisms, but in modern conditions of ecology, bad economic activity in animal farming, this group of microorganisms favorable and extremely necessary for the body is under a huge pressure so the quantity and quality of each species of these microorganisms is reduced. Therefore, today it becomes urgent to solve the problems of restoring and replenishing the normal flora in a living organism. Probiotic groups of medicines and feed additives successfully cope with this $[3,4,5]$.

Currently, probiotics are secured from plants, water, earth, permafrost, and other natural objects $[6,7,8]$. All of them are united only by the type of microorganisms "probiotics", but the species composition, serovars and serotypes differ significantly from the microflora of mammals and therefore their use for animals does not give satisfactory results.

The purpose of this work is to show the effectiveness of the use of certain probiotics in animal farming of the Amur region. To achieve this aim, it was necessary to solve the following tasks:

1. Select the most effective probiotics for animal farming in the Amur region based on the results obtained;

2. Present the results of using an effective probiotic in different areas of animal farming.

\section{Materials and methods}

The research was conducted from 1994 to 2020 in different livestock farms of the Amur region. The assessment of the condition of animals and processing of the results were made according to the method of S. B. Stefanov and N. S. Kukharenko [9], which includes generally accepted indicators and the rules of the general study of the animal. The utmost attention was paid to psycho-emotional state of the animals. Body mass indicators were obtained when animals were weighed on conventional stationary electronic scales. The obtained digital material was processed using generally accepted methods of variation statistics.

To assess the effectiveness of probiotics, the animals were divided into control (intact) and experimental groups. The animals of the experimental group were fed probiotics with water or food in accordance with the instructions for use. Probiotics in the form of feed additive were obtained from the laboratory of the Federal State Budgetary Institution "AllRussian State Center for Quality and Standardization of Medicines for Animals and Feed", Moscow. Economic efficiency was calculated using the method approved by the Department of Veterinary Medicine of the Russian Federation on February 21, 1997 [10].

\section{Results}

Application of various probiotics. Probiotics were obtained from the Federal State Budgetary Institution "All-Russian State Center for Quality and Standardization of Medicines for Animals and Feed" and were applied to piglets when they were weaned, to poultry after vaccination against infectious laryngotracheitis, to cattle and small animals during transportation from other regions (table 1).

The application of probiotics in all cases had a positive effect in improving the livability of livestock. But among all the probiotics the application of "Intestevit" was the most effective. When using this probiotics, the livability of all farm animals was $94.8 \%$. The effect of "Intestevit" was always visually noticeable: animals endured any stress more calmly, consumed food and water more actively and quickly, and regained body weight quickly. The effectiveness of this probiotic in different animal species is shown in table 2. 
Table 1. Application of probiotics for the prevention of stress.

\begin{tabular}{|c|c|c|c|c|c|c|c|}
\hline \multirow[b]{2}{*}{ Specimen } & \multirow{2}{*}{$\begin{array}{l}\text { Name of the } \\
\text { farm }\end{array}$} & \multirow{2}{*}{$\begin{array}{l}\text { Period } \\
\text { of } \\
\text { appli- } \\
\text { cation }\end{array}$} & \multirow{2}{*}{$\begin{array}{l}\text { Animal } \\
\text { species }\end{array}$} & \multicolumn{2}{|c|}{$\begin{array}{c}\text { Number of } \\
\text { heads }\end{array}$} & \multicolumn{2}{|c|}{ Livability,\% } \\
\hline & & & & $\begin{array}{l}\text { con- } \\
\text { trol }\end{array}$ & $\begin{array}{c}\text { exper- } \\
\text { imenta } \\
1\end{array}$ & $\begin{array}{l}\text { con- } \\
\text { trol }\end{array}$ & $\begin{array}{l}\text { experi- } \\
\text { mental }\end{array}$ \\
\hline $\begin{array}{c}\text { Imunobac- } \\
\text { terin }\end{array}$ & $\begin{array}{c}\text { Pig farm } \\
\text { "Krestovozdviz } \\
\text { hensky" }\end{array}$ & 1994 & piglets & 140 & 140 & 89.4 & 57.8 \\
\hline $\begin{array}{c}\text { Bifi- } \\
\text { dumbacte- } \\
\text { rin } \\
\end{array}$ & $\begin{array}{c}\text { LLP } \\
\text { "Pervomayskoe } \\
"\end{array}$ & $\begin{array}{l}1994- \\
1996\end{array}$ & piglets & 280 & 240 & 90.1 & 50.4 \\
\hline $\begin{array}{l}\text { Streptobi- } \\
\text { fid-forte }\end{array}$ & $\begin{array}{l}\text { Research Insti- } \\
\text { tute of Soy }\end{array}$ & $\begin{array}{l}1994- \\
1996\end{array}$ & piglets & 4200 & 3800 & 89.6 & 57.1 \\
\hline Intestevit & $\begin{array}{l}\text { LLP "Amurba- } \\
\text { con" }\end{array}$ & 1996 & piglets & 238 & 242 & 92.8 & 64.0 \\
\hline Intestevit & $\begin{array}{c}\text { LLC "APC } \\
\text { Amurptitseprom } \\
"\end{array}$ & $\begin{array}{l}2005- \\
2007\end{array}$ & $\begin{array}{l}\text { chicken } \\
\text { broilers }\end{array}$ & 19200 & 19400 & 94.4 & 89.9 \\
\hline Intestevit & $\begin{array}{c}\text { LLC "APC } \\
\text { Amurptitseprom } \\
\\
\end{array}$ & $\begin{array}{l}2000- \\
2009\end{array}$ & $\begin{array}{l}\text { egg- } \\
\text { producing } \\
\text { chickens }\end{array}$ & 20600 & 20800 & 99.5 & 92.0 \\
\hline Intestevit & $\begin{array}{l}\text { Private farm- } \\
\text { steads in } \\
\text { Chigiri village } \\
\text { of Blagovesh- } \\
\text { chensk district }\end{array}$ & 2008 & $\begin{array}{l}\text { egg- } \\
\text { producing } \\
\text { chickens }\end{array}$ & 520 & 580 & 84.2 & 36.6 \\
\hline $\begin{array}{l}\text { Streptobi- } \\
\text { fid-forte }\end{array}$ & $\begin{array}{c}\text { FSUAE "Poly- } \\
\text { anoe" }\end{array}$ & 2007 & piglets & 420 & 380 & 89.5 & 53.9 \\
\hline $\begin{array}{c}\text { Imunobac- } \\
\text { terin }\end{array}$ & $\begin{array}{c}\text { JSC "Agrofirma } \\
\text { ANK" }\end{array}$ & 2000 & cattle & 100 & 50 & 85.6 & 53.8 \\
\hline Intestevit & $\begin{array}{c}\text { Kozmo- } \\
\text { dem'yanovka } \\
\text { village, } \\
\text { Ivanovsky dis- } \\
\text { trict }\end{array}$ & 2005 & cattle & 510 & 512 & 98.8 & 51.4 \\
\hline Intestevit & $\begin{array}{l}\text { LLC "Agro- } \\
\text { S.E.V." }\end{array}$ & $\begin{array}{l}2014- \\
2015\end{array}$ & piglets & 171 & 156 & 96.1 & 78.8 \\
\hline Intestevit & $\begin{array}{l}\text { LLC "Dimsko- } \\
\text { ye" }\end{array}$ & 2014 & cattle & 100 & 100 & 98.0 & 97.0 \\
\hline \multicolumn{4}{|c|}{ Total } & 46479 & 46400 & 92.3 & 65.2 \\
\hline
\end{tabular}

During production stresses in the studied animals, the application of probiotic "Intestevit" gave a positive result in the form of an increase in the livability of livestock in the range of $7 \%$ to $50 \%$ (table 2 ), and the economic effect was higher by $23.4-25.9 \%$ than in the animals in the control groups.

Therefore, in 2014 the Department of Science and Technology Policy and Education of the Ministry of Agriculture of Russia instructed us to work in this direction (approved and signed by Director P. I. Burak, February, 2014) in order to correct the prevention of transport stress in animals. 
Table 2. Effectiveness of using probiotic "Intestevit" in animals of different species.

\begin{tabular}{|l|c|c|c|c|c|c|}
\hline \multirow{2}{*}{ Indicators } & \multicolumn{2}{|c|}{ Piglets } & \multicolumn{2}{c|}{ Cattle } & \multicolumn{2}{c|}{ Poultry } \\
\cline { 2 - 7 } & control & $\begin{array}{c}\text { experi- } \\
\text { mental }\end{array}$ & control & $\begin{array}{c}\text { experi- } \\
\text { mental }\end{array}$ & control & $\begin{array}{c}\text { experi- } \\
\text { mental }\end{array}$ \\
\hline $\begin{array}{l}\text { Total number } \\
\text { of animals, } \\
\text { heads }\end{array}$ & 520 & 503 & 512 & 510 & 305 thous. & 304 thous. \\
\hline Loss, heads & 370 & 41 & 245 & 6 & 46 thous. & 15 thous. \\
\hline Livability,\% & 29 & 92 & 52 & 99 & 85 & 92 \\
\hline $\begin{array}{l}\text { Economic } \\
\text { efficiency, } \\
\text { rub. }\end{array}$ & +2.81 & +12.01 & -3.39 & +14.4 & +10.05 & +13.56 \\
\hline
\end{tabular}

\subsection{Changes in the psycho-emotional state of animals}

Were studied on cattle after long transportation, as well as on piglets when they were weaned from their mothers. The results are presented in tables 3-6.

The duration of transportation of cattle (heifers) by road to the Amur region was 4 days. This livestock was given probiotic "Intestevit" once a day with feed for 10 days before transportation. Upon arrival at the farm, the animals received the same probiotic for 7 days more in a dose according to the instructions. The psycho-emotional state of the heifers was determined by 8 indicators and 47 signs. When analyzing the results, the following factors were taken into account: the animal's temperament, temper, behavior, reflexes, look, pupil condition, muscle tone, and sweating (table 3).

Table 3. Negative signs of the psycho-emotional state of heifers during transportation.

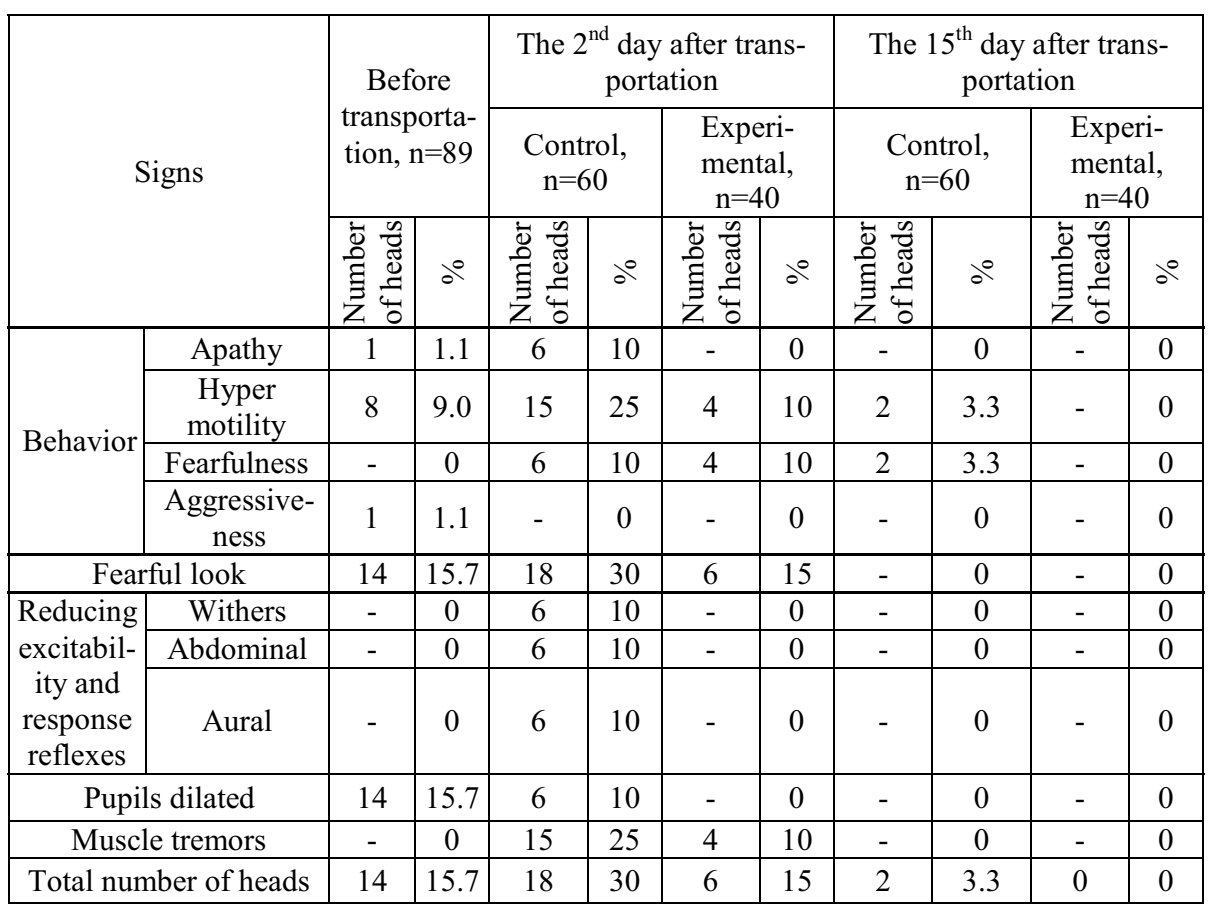


Before transportation 14 heifers $(15.7 \%)$ of the total number of examined livestock showed apathy, fearful look, dilated pupils; hyper motility was in $8 \%$ of animals, and one animal was aggressive.

On the second day after transportation, the animals in the control group were more violent and scared. Of the 60 heads, 6 had apathy, 15 had hyper mobility, 6 had fearfulness and dilated pupils, and 18 had a fearful look. The response to irritation was lowered in 6 heifers and 15 were observed to have muscle tremors.

The animals that were treated with probiotic "Intestevit" were calmer and more balanced, only 4 out of 40 heads showed signs of fearfulness and hyper motility, a fearful look was in 6 heads, and muscle trembling was in 4.

Studying the state of livestock for the entire period of transportation, it was found out that by the time of transportation there were $75.3 \%$ clinically healthy animals, the rest of them $(24.7 \%)$ had negative signs. Moreover, the control group included all healthy animals, while the experimental group included only 34 heads, and 6 animals were problematic. On the second day after transportation in the control group there was only one animal that was transported safely while the remaining 57 heads $(95 \%)$ were clinically identified with different signs of a psycho-emotional state disorder. In the group of animals that were given the probiotic "Intestevit", there were $85 \%$ problematic animals, which is $10 \%$ less than in the control group, taking into account that the experimental group already had problematic animals, and there were 6 healthy animals, which is $10 \%$ more than in the control group.

Thus, long transportation disrupts the psycho-emotional state of animals, which is clearly manifested immediately after transportation in the form of fearfulness, hyper motility, reduced responses and muscle tremors. Disappearance of visual behavior deviations in the main mass of livestock occurs on the $15^{\text {th }}$ day after transportation.

The results of studies conducted in 2014 of the psycho-emotional state of piglets with the use of probiotic «Intestevit" for post-weaning stress are presented in table 4.

Table 4. Psycho-emotional state of piglets under post-weaning stress.

\begin{tabular}{|c|c|c|c|c|c|}
\hline \multirow{2}{*}{\multicolumn{2}{|c|}{ Indicators }} & \multicolumn{2}{|c|}{ Control group } & \multicolumn{2}{|c|}{ Experimental group } \\
\hline & & $\begin{array}{c}\text { Before } \\
\text { weaning }\end{array}$ & $\begin{array}{c}\text { After } \\
\text { weaning }\end{array}$ & $\begin{array}{c}\text { Before } \\
\text { weaning }\end{array}$ & $\begin{array}{c}\text { After } \\
\text { weaning }\end{array}$ \\
\hline \multicolumn{2}{|c|}{ Number of animals in the group } & 198 & 156 & 178 & 171 \\
\hline \multicolumn{2}{|c|}{ Apathy, rapid fatiguability } & 1 & 16 & 1 & 3 \\
\hline \multicolumn{2}{|c|}{ Agitated behavior, hyper motility } & 0 & 17 & 0 & 6 \\
\hline \multicolumn{2}{|c|}{ Muscle tone is lowered or lost } & 0 & 27 & 1 & 3 \\
\hline \multicolumn{2}{|c|}{ The gait is shaky, uncertain } & 0 & 2 & 1 & 3 \\
\hline \multicolumn{2}{|c|}{ Fast feed intake } & 0 & 39 & 0 & 28 \\
\hline \multirow{2}{*}{ Total } & Quantity & 1 & 148 & 4 & 46 \\
\hline & $\%$ & 1 & 94.8 & 2.2 & 26.9 \\
\hline
\end{tabular}

In the total number of piglets the effect of industrial stress was clearly manifested by signs of a breakdown of the psycho-emotional state: lethargy, rapid fatigue, apathy in $10.2 \%$ of piglets; disturbed behavior, hyper motility in $10.8 \%$; the decrease or loss of muscle tone in $17.3 \%$; shaky, uncertain gait in $1.2 \%$, and fast feed intake in $25 \%$ of piglets.

The results of studies of the psycho-emotional state of piglets conducted in 2015 with the application of probiotic "Intestevit" one time in the morning feeding and "Immunofan" in doses specified in the manual, for post-weaning stress are presented in table 5 . The psycho-emotional state was determined by 9 indicators and 48 signs; the negative signs are presented and they characterize the reaction of the psycho-emotional state of piglets during the experiment. 
Table 5. Psycho-emotional state of piglets during weaning.

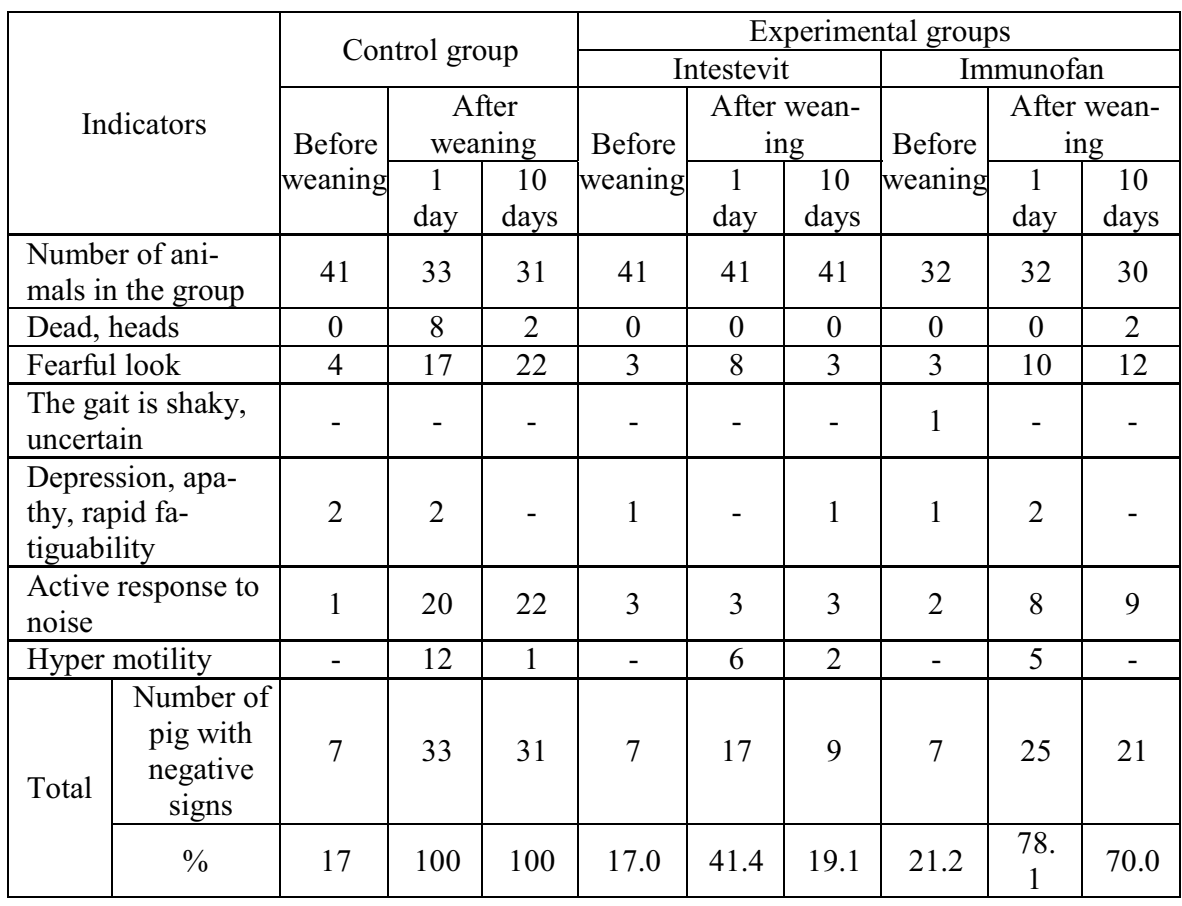

Analysis of the results presented in table 5 confirms that the psycho-emotional state of piglets changed dramatically in the control group and in the second experimental group where "Immunofan" was used. They became excited, fearful, searching for something; they actively moved and reacted to the noise. On the 10th day after weaning, the stress response indicators in these groups worsened.

\subsection{The dynamics of body weight of animals experiencing stress}

Was determined in large and small cattle after long transportation (Fig. 1,2), and in piglets when they were weaned from their mothers (table 6).

The dynamics of the weight of heifers that were transported for 4 days is shown in the form of its decrease (Fig. 1). Before transportation, the average weight of heifers was 572 $\mathrm{kg}$ in the control group and $577 \mathrm{~kg}$ in the experimental group. After transportation, all animals had a decrease in body weight: in the control group it was by an average of $33 \mathrm{~kg}$ $(5 \%)$, in the experimental group by $28 \mathrm{~kg} \mathrm{(4 \% );} \mathrm{the} \mathrm{difference} \mathrm{in} \mathrm{body} \mathrm{weight} \mathrm{loss} \mathrm{between}$ the groups was $15 \%$.

After the next control weigh (a month later), the animals receiving "Intestevit" had a complete gain of body weight, while in the control group, the animal weight indicators did not change.

The duration of transportation of small cattle was 11 days. From the total number of livestock (119 heads), three weight groups were allocated: the first had animals weighing from 25 to $35 \mathrm{~kg}$ (the main herd); the second had animals weighing from 36 to $40 \mathrm{~kg}$; the third had animals weighing more than $41 \mathrm{~kg}$. Probiotic "Intestevit" was applied only after transporting animals, according to the instructions. The results are shown in figure 2. 


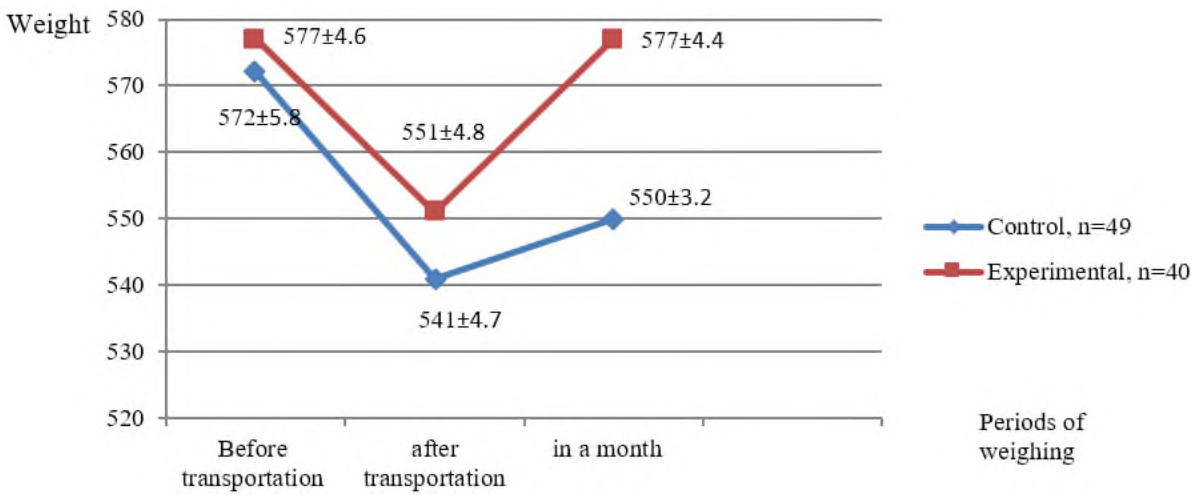

Fig. 1. Dynamics of body weight of heifers, kg.

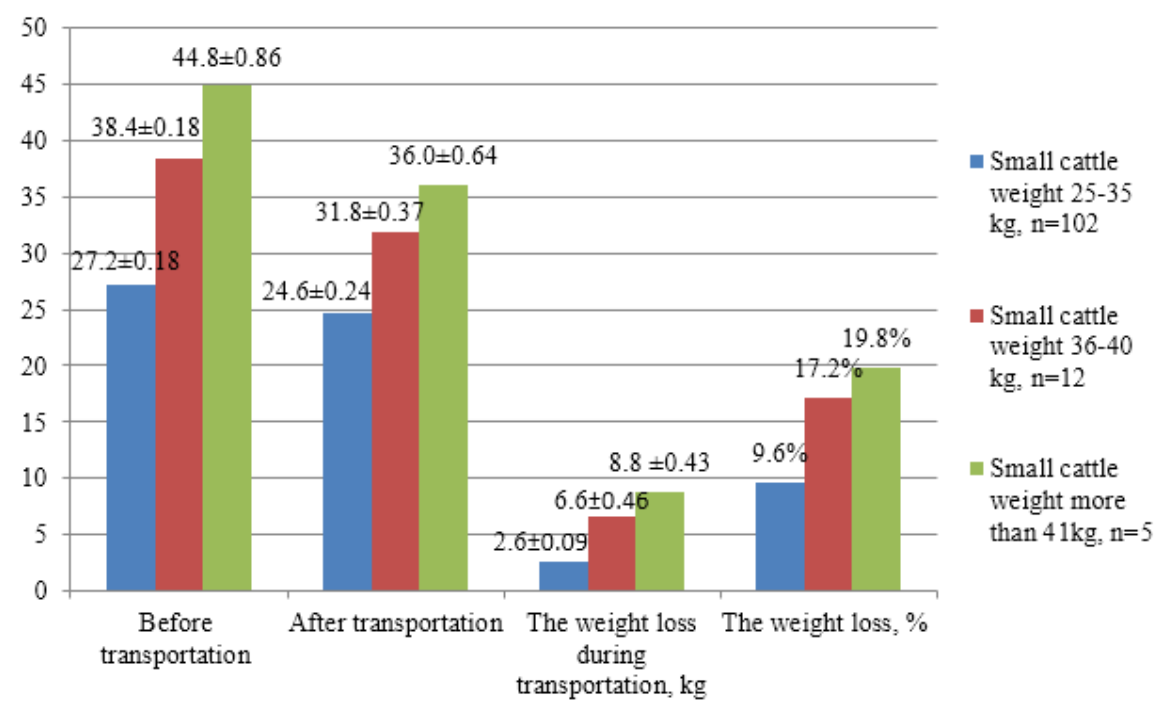

Fig. 2. Dynamics of the weight of sheep when they are transported from another region, $n=119$.

The greatest weight loss of animals on average was $8.8 \mathrm{~kg}$ and was observed in the third group of animals (19.8\%). The animals of the first weight group where their average weight was $27.2 \mathrm{~kg}$ reacted most easily to long-term transport stress. In this group, the decrease in live weight was 2 times less $(9.6 \%)$ than in animals of the third group. In the second group of animals where the average weight was $38.4 \mathrm{~kg}$, there was a decrease of $6.6 \mathrm{~kg}(17.2 \%)$. Thus, the greatest loss of live weight occurred in the more well-fed animals of the third group with the weight of more than $41 \mathrm{~kg}$.

The results of studies of the dynamics of body weight of piglets under post-weaning stress are presented in table 6.

Table 6. Weight of piglets, $\mathrm{kg}, \mathrm{n}=114$.

\begin{tabular}{|l|c|c|c|}
\hline \multicolumn{1}{|c|}{ Indicators } & Control group & Intestevit & Immunofan \\
\hline Number of piglets at birth & 41 & 41 & 32 \\
\hline Weight of 1 pig, kg & 1.5 & 1.7 & 1.8 \\
\hline Number of piglets to be weaned & 33 & 41 & 32 \\
\hline Weight of 1 pig, kg & 5.8 & 6.0 & 7.4 \\
\hline Number of piglets on the 10th day after weaning & 23 & 40 & 28 \\
\hline Weight of 1 pig, kg & 6.0 & 12.1 & 8.4 \\
\hline
\end{tabular}


The average weight of one piglet (table. 6) in the control group at the time of weaning was $5.8 \mathrm{~kg}$, and on the $10^{\text {th }}$ day after weaning their weight increased by $0.8 \mathrm{~kg}$. In the experimental group where probiotic "Intestevit" was applied the average weight of one piglet at the time of weaning was $6.0 \mathrm{~kg}$, and on the $10^{\text {th }}$ day after weaning, their average weight increased by $6.1 \mathrm{~kg}$. Whereas in the experimental group where "Immunofan" was applied, the average weight of one piglet at the time of weaning was $7.4 \mathrm{~kg}$, and on the $10^{\text {th }}$ day after weaning it increased by $1.0 \mathrm{~kg}$. The obtained results indicate that such a stress factor as weaning in industrial pig production leads to a decrease in the weight of piglets.

During the processing of the obtained material, the attention is paid to the livability of piglets in post-weaning stress. The research results are presented in table 7.

Table 7. Livability of piglets when they are weaned from their mothers, $n=114$.

\begin{tabular}{|c|c|c|c|c|c|c|c|c|c|}
\hline \multirow{4}{*}{ Indicators } & \multirow{2}{*}{\multicolumn{3}{|c|}{ Control group }} & \multicolumn{6}{|c|}{ Experimental group } \\
\hline & & & & \multicolumn{3}{|c|}{ Intestevit } & \multicolumn{3}{|c|}{ Immunofan } \\
\hline & \multirow{2}{*}{$\begin{array}{c}\text { Before } \\
\text { weaning }\end{array}$} & \multicolumn{2}{|c|}{$\begin{array}{c}\text { After } \\
\text { weaning }\end{array}$} & \multirow{2}{*}{$\begin{array}{c}\text { Before } \\
\text { weaning }\end{array}$} & \multicolumn{2}{|c|}{$\begin{array}{l}\text { After wean- } \\
\text { ing }\end{array}$} & \multirow{2}{*}{$\begin{array}{c}\text { Before } \\
\text { weaning }\end{array}$} & \multicolumn{2}{|c|}{$\begin{array}{l}\text { After wean- } \\
\text { ing }\end{array}$} \\
\hline & & $\begin{array}{c}1 \\
\text { day }\end{array}$ & $\begin{array}{c}10 \\
\text { days }\end{array}$ & & $\begin{array}{c}1 \\
\text { day }\end{array}$ & $\begin{array}{c}10 \\
\text { days }\end{array}$ & & $\begin{array}{c}1 \\
\text { day }\end{array}$ & $\begin{array}{c}10 \\
\text { days }\end{array}$ \\
\hline $\begin{array}{l}\text { Number of } \\
\text { animals in } \\
\text { the group }\end{array}$ & 41 & 33 & 31 & 41 & 41 & 41 & 32 & 32 & 30 \\
\hline Loss, heads & 0 & 8 & 2 & 0 & 0 & 0 & 0 & 0 & 2 \\
\hline Total, $\%$ & 0 & 19.5 & 6.1 & 0 & 0 & 0 & 0 & 0 & 6.2 \\
\hline
\end{tabular}

The stress response to weaning of mothers in piglets is most clearly observed in the control group (table 7), so the number of piglets within 10 days after weaning decreased by ten heads, which is $24 \%$ of the loss of livestock in this group. In the second experimental group where animals had "Immunofan" for 10 days, 2 piglets died, which amounted to $6.2 \%$ of the loss of livestock. The best livability was observed in the first experimental group where the probiotic "Intestevit" was applied to piglets as stress prevention. The livability in this group in this case was $100 \%$.

\section{Discussion}

The search and the results obtained allowed us to solve the production problems of animal farming in the Amur region and convincingly propose a probiotic that effectively works on this regional population of different animal species $[11,12]$. Our research results are consistent with the opinion of a number of authors who have also studied the effect of probiotics on the general state of the animal body under production conditions $[4,13,14]$. It has been proved that probiotics have a positive effect on the physiological state of animals, average daily weight gain, puberty and reproductive qualities when raising replacement gilts [15]. In poultry farms aimed at egg and meat production, egg production, the percentage of fertilization of eggs, the output of healthy young animals, livability and other indicators increase against the background of the probiotics application [16,17].

In addition, it has been convincingly proved that "Intestevit" can be used with high efficiency as an antistressant and it successfully solves the problems of transport and production stresses without which animal farming is not possible [11].

\section{Conclusion}

1. The application of probiotics in animal industry of the Amur region showed a positive effect in all cases, but "Intestevit" has the highest efficiency ( $94.8 \%$ of live stock); it is 
made in the laboratory of the Federal State Budgetary Institution "All-Russian State Center for Quality and Standardization of Medicines for Animals and Feed» and it is based on the collection of samples of probiotics from the nomenclature of microflora characteristic of animals from different regions of the Russian Federation. In groups where animals were treated with probiotic "Intestevit", the economic effect was higher by $23.4-25.9 \%$.

2. Probiotic "Intestevit" can be successfully used in different sectors of livestock production in the Amur region in various situations of gastrointestinal pathology and when it is necessary to deal with transport and industrial stress.

\section{References}

1. G. A. Nozdrin, A. B. Ivanova, A. G. Nozdrin Probiotics based on Bacillus subtilis and their role in the health of animals of different species, Siberian Bulletin of agricultural science, 1,7, 64-68 (2006)

2. B. Gedek Probiotics in animal feeding, Effects of performance and animal health, 8, 21-23 (2008)

3. M.F. Khalid, M.A. Shahzad, M. Sarwar, A.U. Rehman, M. Sharif, N. Mukhtar Probiotics and lamb performance: a review, African Journal of Agricultural Research, 6(23), 5198-5203.(2011)

4. A. N. Panin, N. I. Malik Probiotics as an integral component of rational animal feeding Veterinary science, 7, 3-6 (2006)

5. A.M. Saleem, A.I. Zanouny, A.M. Singer Growth performance, nutrients digestibility, and blood metabolites of lambs fed diets supplemented with probiotics during pre- and post-weaning period Asian-Australasian, Journal Of Animal Sciences, 30(4), 523-530 (2017)

6. B. T. Stegny, S. A. Guzhvinskaya Prospects for the use of probiotics in animal farming, Veterinary science, 11, 24 (2006).

7. D. Curro, G. Ianiro, S. Pecere, S. Bibbo, and G. Cammarota Probiotics, fibre and herbal medicinal products for functional and inflammatory bowel disorders, British Journal of Pharmacology, 174(11), 1426-1449 (2017) doi: 10.1111/bph.13632.

8. H.H. Musa, S.L. Wu, C.H. Zhu The potential benefits of probiotics in animal production and health, Journal of Animal and Veterinary Advances, 8(2), 313-321. (2009)

9. S.B. Stefanov, N.S. Kukharenko Accelerated method of quantitative comparison of morphological features: scientific and methodological recommendations 28 (1989)

10. A.D. Tretyakov Veterinary legislation 4, 671(1988)

11. N.S. Kukharenko, F.O. Fyodorova, M.Yu. Shchelkanov Response of farm animals to transport stress and its correction with probiotics South of Russia: Ecology, Development, 14, 2, 87-98 (2019)

12. N. S. Kukharenko, A.O. Fedorova Development of young animals in the post-fetal period from cows imported from other regions, Ekoloji: Foundation Environmental Protection \& Research-FEPR Received , 27, 106, 293-299 (2018)

13. V. N. Nikulin, I. N. Boyko, T. E. Palagina, A. B. Shamraev Probiotics as regulators of metabolic processes, News of the Orenburg State Agrarian University, 1, 5-1, 139-142 (2005)

14. R. V. Nekrasov, A. G. Chabaev, N. I. Anisova Probiotic of a new generation in cow feeding Achievements of Science and Technology of the Agro-Industrial Complex, 3, 38 (2013) 
15. N. I. Kuznetsov, T. I. Elizarova, A. B. Brunner Increasing the productivity of sows and young pigs when using, Intestevit Bulletin of the Voronezh State Agrarian University, 9, 144-148 (2004)

16. N. V. Danilevskaya Pharmacological aspects of the use of probiotics, Veterinary science, 11, 18. (2005)

17. L. N. Skvortsova, D. V. Osepchuk, H. A. Pyshmantseva Efficiency of using probiotics of domestic production in growing broiler chickens, 5, 18-19. (2008) 